\title{
The influence of physicochemical environment on the distribution and abundance of mangrove gastropods in Ngurah Rai Forest Park Bali, Indonesia
}

\author{
AJIE IMAMSYAH ${ }^{1, \boldsymbol{\vartheta}}$, I WAYAN ARTHANA ${ }^{1,2}$, IDA AYU ASTARINI ${ }^{1,3}$ \\ ${ }^{1}$ Environmental Sciences Program, Postgraduate Program, Universitas Udayana. Jl. PB Sudirman, Denpasar 80232, Bali, Indonesia. \\ Tel./fax.: +62-361-223797, `email: ajieimamsyah21@gmail.com \\ ${ }^{2}$ Department of Aquatic Resources Management, Faculty of Marine Sciences and Fisheries, Universitas Udayana. Jl. Raya Kampus Unud, Jimbaran, \\ Badung 80361, Bali, Indonesia \\ ${ }^{3}$ Department of Biology, Faculty of Mathematics and Natural Sciences, Universitas Udayana. J1. Raya Kampus Unud, Jimbaran, Badung 80361, Bali, \\ Indonesia
}

Manuscript received: 25 April 2020. Revision accepted: 20 June 2020.

\begin{abstract}
Imamsyah A, Arthana IW, Astarini IA. 2020. The influence of physicochemical environment on the distribution and abundance of mangrove gastropods in Ngurah Rai Forest Park Bali, Indonesia. Biodiversitas 21: 3178-3188. Ngurah Rai Forest Park is the widest mangrove ecosystem in Bali that close to the business center and tourism area. The strategic location of the Ngurah Rai Forest Park is estimated to produce anthropogenic waste that can disrupt the gastropod population and stability of the mangrove ecosystems. This study aims to analyze the mangrove density, distribution, and abundance of gastropods based on the quality of the biophysical environment. Mangrove data collection was carried out using a plot transect of $10 \mathrm{~m}$ x $10 \mathrm{~m}, 5 \mathrm{~m}$ x $5 \mathrm{~m}$, and $1 \mathrm{~m}$ x $1 \mathrm{~m}$. Meanwhile, samples gastropods were collected on a plot transect of $0.5 \mathrm{~m} \times 0.5 \mathrm{~m}$ in plot transect of $5 \mathrm{~m} \times 5 \mathrm{~m}$. A total of 11 gastropods species and 6 mangrove species were recorded in this study. The dominant gastropods species found were Assiminea brevicula $\left(28 \mathrm{ind} / \mathrm{m}^{2}\right)$. Species mangrove of Sonneratia alba and Rhizophora apiculata found were in all study sites with tree density values of $1000 \mathrm{ind} / \mathrm{ha}$. Subsequently, the ecological index calculation results show that the diversity index (H') (2.89-3.2), evenness index (E) (0.87-0.93), and dominance index (C) (0.12-0.17). Based on the Principal Component Analysis (PCA) found was Assiminea brevicula spread on sand and silt substrates and adaptive to the temperature condition, salinity, $\mathrm{pH}$, and dissolved oxygen. Furthermore, other analysis results showed that Cerithidea cingulata, Cerithidea quadrata, Littoraria articulata, and Littoraria scabra were found on clay substrate with high C-organic content. In conclusion, gastropods are evenly distributed and no species dominate the ecosystems.
\end{abstract}

Keywords: Coastal environment, ecological index, ecosystem, gastropods, mangrove

\section{INTRODUCTION}

Mangrove ecosystem has unique vegetation where their growth depends on tidal conditions, salinity, and generally grows well on mud substrates that are rich in organic matter. As a form of adaptation, mangrove species have a specific root system that is adaptive to existing environmental conditions (Norris et al. 2019). The mangrove aerial rooting system, salinity, and substrates determined the zone of mangrove species. (Wijayasinghe et al. 2018; Muhammad-Nor et al. 2019; Virgulino-Junior et al. 2019). Mangrove ecosystem is arranged into three zones. Mangrove species closest to sea are found Avicennia sp., and Sonneratia sp. More toward the land commonly found Rhizophora sp. associated with Bruguiera sp., and Xylocarpus sp. Next up is the transition zone which is dominated by Nypa fruticans and several other species such as Achantus sp., Aegiceras sp., Excoecaria sp., Lumnitzera sp., and Scyphiphora sp. (Sreelekshmi et al. 2018; Basyuni et al. 2019; Priosambodo et al. 2019). Mangrove ecosystem in the coastal region makes the ecosystem has high productivity and biodiversity. Mangrove ecosystem has all the potential to be developed both in terms of economic, physical, and ecological (Koch et al. 2009; Buncag et al.
2019; Hilaluddin et al. 2020). Mangrove ecosystems are used by the community as charcoal, firewood, medicine, and others. Physically, the mangrove ecosystem serves to protect the coast from tidal waves, prevent abrasion, and erosion. After that, the ecological utilization of mangrove ecosystems namely as a place for spawning ground, nursery ground, and feeding ground for various marine organisms (Sheaves et al. 2016; Marley et al. 2020), one of which is gastropods.

The distribution of gastropods is strongly influenced by biotic and abiotic factors. Biotic factors consist of predators, life cycles, and food sources (Peng et al. 2017; Abdelhady et al. 2018). In this case, mangrove trees as producers play an important role in gastropods survival. Leaves that fall from mangrove trees become food sources for gastropods. Subsequently, abiotic factors consist of environmental biophysical such as temperature, salinity, $\mathrm{pH}$, dissolved oxygen, and substrate types. Temperature is one of the important parameters for supporting gastropods because of the temperature changes can affect the gastropods metabolism (Latupeirissa et al. 2020). Furthermore, salinity can affect gastropods horizontally and vertically. Generally, gastropods are found in coastal areas because changes in salinity are more stable when to 
compared close to estuaries. Estuaries are very susceptible to environmental pressures because estuaries are the first areas to be contaminated waste disposal from the mainland (Villate et al. 2017), so that gastropods are more suitable for breeding in coastal areas. In addition, substrate types also affect the distribution of gastropods in mangrove ecosystems. Commonly, gastropods are found on mud and clay substrates contain more organic matter than sand substrate. Organic matter content is used by gastropods as a food source derived from mangrove litter through the decomposition process by microorganisms (Ariyanto 2019; Pazira et al. 2019). Therefore, the presence of gastropods in mangrove ecosystems can describe a good environmental condition and be able to maintain mangrove ecosystem stability. According to Savic et al. (2016); Litaay et al. (2017); Reguera et al. (2018); Baroudi et al. (2020), gastropods have high economic values and can be used as bioindicators of environmental quality.

Ngurah Rai Forest Park is the widest mangrove ecosystems in Bali, Indonesia. Administratively, this area is located in Badung Regency with an area of 627 ha and Denpasar City covering of 746.5 ha. Ngurah Rai Forest Park Bali located in a very strategic area, close to the tourism area and business center in Bali. This area is divided into 14 utilization blocks where 5.8 ha is used as the arrangement of springs, landfills covering an area of 36.7 ha, pond rehabilitation covering an area of 70.7 ha, and utilization as a business center, trade, and home residents covering an area of 1098.6 ha. The utilization is estimated to produce anthropogenic waste which disrupts mangrove ecosystems so that it can decrease gastropods habitat. Considering the importance of gastropods function, it is necessary to study the influence of physicochemical environment on the distribution and abundance of mangrove gastropods in Ngurah Rai Forest Park Bali.

\section{MATERIALS AND METHODS}

\section{Study area}

This research was conducted in September until December 2019 in Ngurah Rai Forest Park, Bali, Indonesia. The study sites were divided into 5 stations namely Mertasari Beach (842'41.64'S, 115 14'42.54'E) (Station 1), MIC Office (Mangrove Information Center) (843'56.66'S, 115 11'48.24'E) (Station 2), Mati River (8'44'31.47'S, $115^{\circ} 11^{\prime} 1.38^{\prime \prime}$ ) (Station 3), Kedonganan Village ( $8^{\circ} 45^{\prime} 41.01^{\prime}$ S, $\left.115^{\circ} 10^{\prime} 51.62^{\prime \prime} \mathrm{E}\right)$ (Station 4), and Tanjung Benoa ( $8^{\circ} 46^{\prime} 44.12^{\prime}$ 'S, $115^{\circ} 13^{\prime} 0.29^{\prime \prime E}$ ) (Station 5) (Figure 1). Samples were collected using purposive sampling where the process must pay attention to environmental variability that is easily understood and sampling points that are easily accessible.

\section{Procedures \\ Mangrove data collection}

A sampling of mangrove vegetation was carried out using line-transect that stretches from the land boundary to the sea level where mangroves grow. For sampling, each line transect was subdivided into 3 substations and each substation was further divided into 2 square plots. Transect $10 \times 10 \mathrm{~m}^{2}$ was used to observe mangrove trees, transect 5 x $5 \mathrm{~m}^{2}$ for observing mangrove saplings, and transect 1 x 1 $\mathrm{m}^{2}$ for observing mangrove seedlings (Bengen 2004). Subsequently, the mangrove trees, saplings, and seedling were identified using Kitamura et al. (1997).
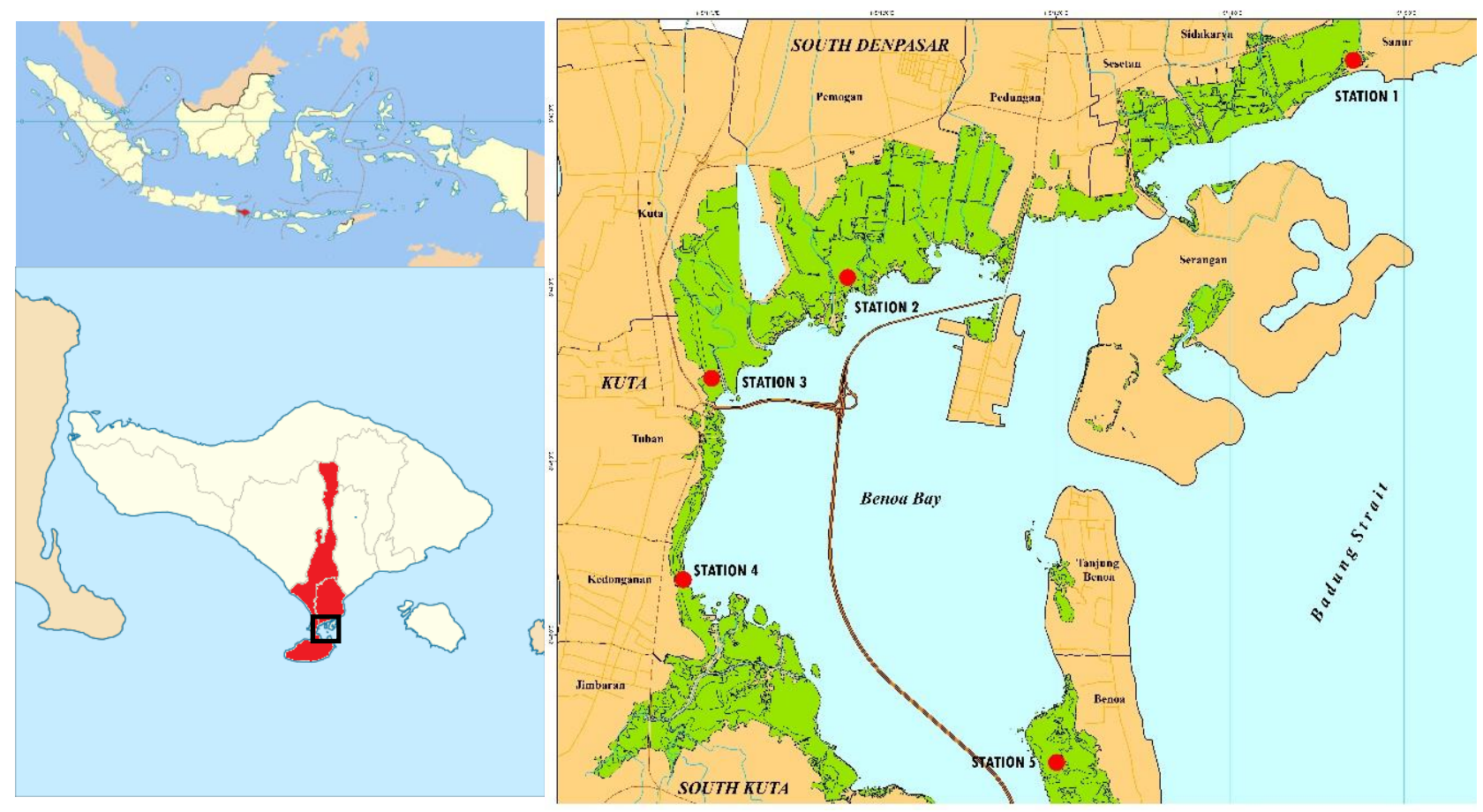

Figure 1. Research location in Ngurah Rai Forest Park Bali, Indonesia 


\section{Gastropods data collection}

Gastropods data collection was sampled vertically in the plot. Sampling was carried out at low tide to facilitate sample collection. Gastropods observed were only species that were in $0.5 \times 0.5 \mathrm{~m}^{2}$ transect plots in $5 \times 5 \mathrm{~m}^{2}$ mangrove transect plots in mangrove roots, stems, and leaves. Samples were washed using aquadest and preserved using alcohol 70\%. Subsequently, the sample was identified using Dharma (2005).

\section{Biophysical environment data collection}

Biophysical environment samples (temperature, salinity, $\mathrm{pH}$, dissolved oxygen, and substrate) were collected using an in-situ sampling technique. Thereafter, water temperature measurements were carried out using a water thermometer. The water thermometer was inserted into the water for approximately 15 seconds and the thermometer scale shows the results. Water salinity measurements were performed with a refractometer. The next step is to open the glass and put two drops of water, then close the glass. Point the refractometer at sunlight and the measurement results can be seen. The $\mathrm{pH}$ of the water was measured using a $\mathrm{pH}$ meter. Insert the tip of the $\mathrm{pH}$ meter sensor for approximately 15 seconds and then the $\mathrm{pH}$ value was obtained. Dissolved oxygen was measured using the DO meter. Dip the DO meter sensor into the water for approximately 15 seconds and the measurement results were recorded. Subsequently, substrate analysis was carried out in Aquaculture Environmental Laboratory, Faculty of Fisheries and Marine Sciences, Bogor Agricultural University. Substrate samples were further analyzed to determine the substrate granules and organic matter content. Measurement of the substrate was carried out using sieving method where the substrate granules refer to the Wentworth Scale namely Clay $(<4 \mu \mathrm{m})$, silt $(4 \mu \mathrm{m}-63$ $\mu \mathrm{m})$, sand $(63 \mu \mathrm{m}-2 \mathrm{~mm})$, and gravel $(>2 \mathrm{~mm})$ (Bloot and Pye 2001).

\section{Data analysis}

Gastropods density

Density is the number of individuals per unit area (Krebs 1989):

$$
\mathrm{D}=\frac{\mathrm{Ni}}{\mathrm{A}}
$$

Where: D: Individual density (ind $\left./ \mathrm{m}^{2}\right)$; Ni: Sum of individuals; A: Sample plot area $\left(\mathrm{m}^{2}\right)$.

\section{Diversity index ( $\left.H^{\prime}\right)$}

The formula for calculating diversity index is as follows (Magurran 2004):

$$
\mathrm{H}^{\mathrm{n}}=-\sum_{i=1}^{\mathrm{s}}(\mathrm{P} i \log 2 \mathrm{P} i)
$$

Where: H': Diversity index of Shannon-Wiener; Pi: Sum of individual species per total number of individuals $(\mathrm{ni} / \mathrm{N})$; ni: Sum of the individual in type $i ; \mathrm{N}$ : Total numbers of individuals; s: Sum of species.

The relationship between diversity index with the stability of the gastropod community is as follows: $0<\mathrm{H}^{\prime}$ $\leq 1$ : Low species diversity (unstable); $1<\mathrm{H}^{\prime} \leq 3$ : Moderate species diversity; H'> 3: High species diversity (stable).

Evenness index $(E)$

The formula for calculating evenness index is as follows (Magurran 2004):

$$
\mathrm{E}=\frac{\mathrm{H}^{\mathrm{N}}}{\mathrm{H} \max }
$$

Where: E: Evenness index; H': Diversity index of Shannon-Wiener; $\mathrm{H}_{\max }$ : Maximum species diversity $(\log 2$ s); s: Sum of species.

Criteria for evenness index results are as follows: $\mathrm{E} \leq$ 0,5: Low evenness; $0,5<\mathrm{E} \leq 0.75$ : Moderate evenness; $\mathrm{E}$ $>0,75$ : High evenness.

\section{Dominance index $(C)$}

The formula for calculating the dominance index is as follows (Magurran 2004):

$$
\mathrm{C}=\sum_{i=1}^{\mathrm{s}}(\mathrm{Pi})^{2}
$$

Where: C: Dominance index; Pi: Sum of individual species per total number of individuals (ni/N).

Criteria for dominance index results are as follows: $0<$ $\mathrm{C}<0,5$ : Low dominance (No species dominate); $0,5<\mathrm{C}<$ 1: High dominance (There are species that dominate).

\section{Mangrove density}

Mangrove species density is the number of stands a species of mangrove compared to the area of observation (Bengen 2004):

$$
\mathrm{Di}=\frac{\mathrm{ki}}{\mathrm{A}}
$$

Where: Di: Species density (ind $/ \mathrm{m}^{2}$ ); ni: Total number of stands; A: Sample plot area $\left(\mathrm{m}^{2}\right)$.

\section{Association of gastropods based on environmental characteristics}

The relationship between the distribution of gastropods based on environmental parameters was determined using Principal Component Analysis (PCA) with XLStat 2016 software. PCA is a factorial analysis method that can reduce large amounts of data so that interpretation is easier by pulling essential information (Kherif and Latypova 2020). The data matrix consists of research station as individual (rows), while gastropods and mangrove species as quantitative variables (columns). The main purposes of PCA analysis are: (i) extract essential information contained in large data or table matrix; (ii) produce graphical representation to be easily understood; and (iii) study a data or table matrix from similarities between individuals or relationship between variables (Bachelet 1996; Bengen 2000).

\section{Association of gastropods and mangrove species}

The distribution gastropods on mangrove species were determined using Correspondence Analysis (CA). CA is a multivariate technique that converts a data matrix into graphical displays in which the table or data matrix is represented as points (Greenacre and Hastie 1987). The CA 
method is descriptive in which no variable has a more important role than the other variables. The primary purposes of $\mathrm{CA}$ analysis are: (i) looking for a close relationship between the modalities of two characters or variables in a contingency data or table matrix; and (ii) looking for close relationship between all modalities and similarities between individuals based on the configuration of answers in tables or complete disjunctive data matrix (Bengen 2000).

\section{RESULTS AND DISCUSSION}

\section{Physicochemical parameters of water}

The results of the physicochemical parameters (temperature, salinity, $\mathrm{pH}$, and dissolved oxygen) measurements at five research observation in Ngurah Rai Forest Park Bali shows the fluctuation in each physicochemical environment (Table 1). The water temperature is one factor that can affect the condition of mangrove vegetation and gastropods that life surrounding. The water temperature at each research observation approximately $28.3-29.1^{\circ} \mathrm{C}$, in which the lowest temperature was found in Mati River (Station 3) of $28.3^{\circ} \mathrm{C}$ and the highest temperature was observed in MIC Office (Station 2) of $29.1^{\circ} \mathrm{C}$. The difference in temperature due to the high and low density of mangroves. The temperature will increase if the mangrove density is low because of the high intensity of sunlight received by waters, otherwise, the temperature will decrease if the density of mangroves is high. Peng et al. (2016) state that lack of light penetration is the main limiting factor in growth for mangroves. According to Ministry of Environment Decree Number 51 (2004), the optimum temperature for the life of marine organisms ranged between $28-32^{\circ} \mathrm{C}$. Efriyeldi et al. (2020) reported that water temperatures above $40^{\circ} \mathrm{C}$ not too significantly influence the life of mangrove ecosystems. Based on the measurement results, water temperature in the present study is within the normal range and suitable for mangroves and gastropods existence.

Salinity is the salt concentration in water. Water salinity at each research station approximately $21.3-29.6 \%$. Several studies reported the salinity content in mangrove ecosystems has different values. One of the studies from Mitra (2018), the distribution of salinity during monsoon and pre-monsoon was approximately 14.45-18.97\%o. Meanwhile, Xu et al. (2019) collected data from dry season and wet season indicated that average salinity for the dry season was 4.1-23.2\%o. Meanwhile, during the wet season, average salinity decreases to $18.2 \%$. High and low salinity is influenced by evaporation, runoff, and rainfall (Uncles and Stephens 2011; Asri et al. 2015; Geng et al. 2016). The greater intensity of sunlight entering the water column, the higher process of evaporation which causes high salinity, conversely the higher rainfall causes low salinity. According to Ministry of Environment Decree Number 51 (2004), the optimum salinity for marine organisms is not more than $34 \%$ so it can be said that salinity normal for gastropods life in the mangrove ecosystems of Ngurah Rai Forest Park Bali.
Table 1. Physico-chemical parameters in each station

\begin{tabular}{lccccc}
\hline Environmental & \multicolumn{5}{c}{ Research stations } \\
\cline { 2 - 6 } parameters & $\mathbf{1}$ & $\mathbf{2}$ & $\mathbf{3}$ & $\mathbf{4}$ & $\mathbf{5}$ \\
\hline Temperature $\left({ }^{\circ} \mathrm{C}\right)$ & 28.9 & 29.1 & 28.3 & 28.4 & 28.9 \\
Salinity $(\% \mathrm{o})$ & 27.3 & 27.2 & 21.3 & 26.5 & 29.6 \\
pH & 7.18 & 7.28 & 7.09 & 7.25 & 7.2 \\
DO (mg/l) & 3.18 & 4.19 & 2.74 & 4.13 & 4.16 \\
\hline
\end{tabular}

The $\mathrm{pH}$ is the amount of activity of hydrogen ion in water (Boyd et al. 2011). Koch (2001) argued that pH is related to decomposer activity. Decomposer activity will not be optimal if the acidic $\mathrm{pH}$ disrupts mangrove ecosystem growth due to a lack of nutrients and minerals. The results showed $\mathrm{pH}$ values ranged between 7.09-7.25. As a comparison, there are several studies that measurement of $\mathrm{pH}$ water in mangrove ecosystems. According to research conducted at Zuari estuary India by Jayachandran et al. (2018), pH values range from 7.3-7.6. Meanwhile, Sreelekshmi et al. (2020) reported at Sundurban Delta India in which the $\mathrm{pH}$ water values were obtained to 8.14. The difference in $\mathrm{pH}$ was thought to be a litter of leaves, stems, and roots that fall to the ground causing the $\mathrm{pH}$ to become acidic due to the decomposition process. The decomposition process will produce organic acids which can reduce the $\mathrm{pH}$ concentration (Adeleke et al. 2017). Ministry of Environment Decree Number 51 (2004) states that the $\mathrm{pH}$ values between 7-8.5 are considered appropriate for mangrove and marine organisms.

Dissolved Oxygen (DO) is an oxygen concentration in water. DO concentration is one of the most important indicators of the waters biological and chemical (RajwaKuligiewicz et al. 2015). Measurements of DO were carried out to analyze changes in biological and chemical processes in the waters. DO concentration will be high if there is a process of photosynthesis and otherwise DO will below if there is an oxidation process of organic matter and respiration by organisms (Dubuc et al. 2019; Mitra 2019). DO concentration in waters plays a role in the oxidation and reduction of organic and inorganic materials. In aerobic conditions, DO concentration oxidizes organic matter and inorganic materials which can fertilize the waters. Meanwhile, in anaerobic conditions DO concentration reduces chemical compounds in the form of nutrients and gases (Barreto et al. 2018; Shantelle et al. 2018; Lin et al. 2020). This oxidation and reduction process is very important in the effort to reduce the debit of pollution from anthropogenic waste. Subsequently, the results were obtained that DO concentration in waters ranged between 2.74-4.19 mg/l. According to Ministry of Environment Decree Number 51 (2004), DO optimum for marine organisms is $>5 \mathrm{mg} / \mathrm{l}$. The difference in DO concentration was due to the location of the observations that were close to residential areas, tourism, and businesses center to produce anthropogenic waste. Gobler and Baumann (2016); Gedan et al. (2017); Farooq and Siddiqui (2020), states that DO concentration will decrease if the waters are polluted by waste without any prior processing. 
Based on the present finding, DO concentration recorded is not natural and can disrupt overall ecosystem stability.

\section{Characteristics of substrates}

The substrate is a solid material derived from the weathering of rocks process, sedimentation, and transport by water and wind. The substrate is composed of several biogenic materials derived from organisms, autogenic materials from the marine chemical process, residual material, detritus material, and depositional residual material (Barnard et al. 2013; Prarikeslan 2016). Sand, silt, and clay substrates are common soil formation that can be found in many types of forest e.g.: inland forest, island forest, and mangrove forest (Kawaida et al. 2017; Lo et al. 2019). The results of the substrate characteristic measurements at five research observations in Ngurah Rai Forest Park Bali showed that there were differences in the substrates texture (Table 2). The dominant sand substrate was found at station $1(90.25 \%)$, station $4(85.9 \%)$, and station $5(79.04 \%)$. Conversely, the sand substrate has a low value at station $2(33.18 \%)$ and station $3(25.85 \%)$. Thereafter, the silt substrate was observed at station 5 $(19.3 \%)$, station $4(12.91 \%)$, station $1(7.64 \%)$, station 2 $(6.3 \%)$, and station $3(3.35 \%)$, respectively. Moreover, the dominant clay substrate was obtained at station $3(70.8 \%)$ and station $2(60.52 \%)$, while the clay substrate has a low value at station $1(2.11 \%)$, station $5(1.66 \%)$, and station 4 $(1.19 \%)$, respectively. The difference in the texture of the substrate occurs due to the characteristics of the research station which were close to the river and beach. The sand substrate was found in coastal areas due to the influence of currents and waves that can change the composition, size, and shape of the substrate. According to Abdulkarim et al. (2011); Wang et al. (2016); Sane et al. (2020), the waters with strong currents will find coarse granules while the waters with weak currents will settle more fine granules.

Organic matter (C-organic) is all organic materials derived from plant tissues and animals that are alive or dead (Strosser 2010; Reyes and Crisosto 2016; Gmach et al. 2020). C-organic content is a source of productivity and germplasm used by gastropods. The main source of Corganic content derived from mangrove litter. The high production of mangrove litter makes the higher of Corganic content. Mangrove litter that falls then has a decomposition process that can affect the abundance of gastropods and can play as an indicator of water fertility. Furthermore, the role of the mangrove ecosystems as a producer of C-organic is very important. Damaged mangroves conditions cause low litter production and cause gastropods to be difficult to adapt to environmental conditions.

Tabel 2. Substrates texture on five research stations

\begin{tabular}{ccccc}
\hline \multirow{2}{*}{ Station } & \multicolumn{3}{c}{ Substrate Texture (\%) } & \multirow{2}{*}{ C-organic (\%) } \\
\cline { 2 - 4 } & Sand & Silt & Clay & \\
\hline 1 & 90.25 & 7.64 & 2.11 & 2.31 \\
2 & 33.18 & 6.3 & 60.52 & 5.47 \\
3 & 25.85 & 3.35 & 70.8 & 4.27 \\
4 & 85.9 & 12.91 & 1.19 & 2.6 \\
5 & 79.04 & 19.3 & 1.66 & 4.6 \\
\hline
\end{tabular}

The results showed that the C-organic at station 2 $(5.47 \%)$, station $5(4.6 \%)$, station $3(4.27 \%)$, station 4 $(2.6 \%)$, and station $1(2.31 \%)$, respectively. The difference in C-organic was suspected due to the use of mangrove ecosystems that are not following environmental sustainability so that the condition of mangroves is damaged. According to Lugina et al. (2017), misuse the mangrove ecosystems in Ngurah Rai Forest Park Bali is caused by (i) Infrastructure development. Strategically, Ngurah Rai Forest Park is located as a business center and tourism area which cause water pollution can affect coastal ecosystems life. This utilization was further exacerbated by the reclamation that can cause abrasion, sedimentation, and change the structure of mangrove vegetation; and (ii) Land conversion. Ngurah Rai Forest Park is the widest mangrove ecosystem in Bali so that forest managers find it difficult to protect their area. Under this condition, the community utilizes mangroves but not protect the environment e.g.: illegal logging, misuse the mangrove ecosystems as ponds, and others.

\section{Mangrove density}

There were six species were found in the mangrove ecosystems of Ngurah Rai Forest Park Bali. Overall, $S$. alba was recorded the highest density ( $878 \mathrm{ind} / \mathrm{ha}$ ) (Table 3 ). According to previous studies, such as Mulla and Chavan (2017) in the Coast of Ratnagiri India, Widyastuti et al. (2018) in Segara Anakan Mangrove Forest Cilacap, Costa et al. (2019) in the Coast of Metinaro Timor Leste reported that $S$. alba had a high density. $S$. alba is one of the true mangrove species that is adaptive to environmental changes. Polidoro et al. (2010) argued that true mangrove has the ability to the salt exclusion or salt excretion by utilizing pneumatophores or aerial roots, exclusively restricted to tropical intertidal habitats, and adaptive to existing environmental conditions.

Conversely, the lowest density was found $X$. granatum (44 ind/ha) (Table 3). Shah et al. (2016); Dimalen and Rojo (2018) revealed that $X$. granatum had a low density. The low density is due to highly exploited. In Bali, X. granatum seeds are used as cosmetic ingredients and subsequently sold as Balinese products. In Togean Central Sulawesi, $X$. granatum seeds have activity inhibition of tyrosinase and antioxidants which has the potential to brighten the skin (Zamani et al. 2015). Das et al. (2019) reported that leaves, fruits, and barks of $X$. granatum can be processed into medicine for various diseases e.g.: fever, malaria, cholera, dysentery, thrush, and diarrhea. Overall, $S$. alba density is classified as a good condition with a total density value of $3144 \mathrm{ind} / \mathrm{ha}$. Meanwhile, X. granatum density is classified as damage condition with a total density value of $66 \mathrm{ind} / \mathrm{ha}$ (Table 4).

\section{Gastropods density}

Gastropods observations obtained 5 (five) families and 11 (eleven) species that are in 5 (five) research locations in the area of Ngurah Rai Forest Park Bali. The observations consist of 1 species of Assimineidae family (A. brevicula), 
1 species of Fasciolariidae family (Latirus polygonus), 2 species of Littorinidae (L. scabra and L. articulata), 3 species of Neritidae family (Nerita balteata, Vittoida turrita, and Vittoida variegata), and 4 species of Potamididae (C. cingulata, C. quadrata, Terebralia palustris, and Telescopium telescopium). Gastropods density found at the study sites is presented in Figure 2.

Gastropods density calculation results showed that the total density was $153 \mathrm{ind} / \mathrm{m}^{2}$. The highest gastropods density was found in station $2\left(36 \mathrm{ind} / \mathrm{m}^{2}\right)$, followed by station $3\left(30 \mathrm{ind} / \mathrm{m}^{2}\right)$, station $5\left(31 \mathrm{ind} / \mathrm{m}^{2}\right)$, station 1 and station $4\left(28 \mathrm{ind} / \mathrm{m}^{2}\right)$. Species $A$. brevicula were the most common species $\left(28 \mathrm{ind} / \mathrm{m}^{2}\right)$, followed by $C$. quadrata $(24$ $\mathrm{ind} / \mathrm{m}^{2}$ ), and C. Cingulata (23 ind $\left./^{2}\right)$. On the other hand, two rare species recorded which were $L$. polygonus and $V$. variegata with $4 \mathrm{ind} / \mathrm{m}^{2}$ each, respectively. Our finding showed that $A$. brevicula has the highest density which is confirmed by Suartini et al. (2013), in which were found 17 species in Ngurah Rai Forest Park. A. brevicula, $C$. cingulata, and $T$. palustris are the dominant species were found in the research. Nurprasaja (2018) also reported that were found 15 species in Ngurah Rai Forest Park, in which A. brevicula dominated with a total density value of 40 ind $/ \mathrm{m}^{2}$, followed by L. articulata $\left(15 \mathrm{ind} / \mathrm{m}^{2}\right)$, C. cingulata and $C$. quadrata with $2 \mathrm{ind} / \mathrm{m}^{2}$ each, respectively.
Table 4. Standard criteria for mangrove damage

\begin{tabular}{ccc}
\hline Density (ind/ha) $*$ & \multicolumn{2}{c}{ Criteria } \\
\hline$\geq 1500$ & Great & Good \\
$\geq 1000-<1500$ & Medium & Damage \\
$<1000$ & Rarely & Dam
\end{tabular}

Note: *Ministry of Environment Decree Number 201 (2004)

about guidelines criteria determination of mangroves damage

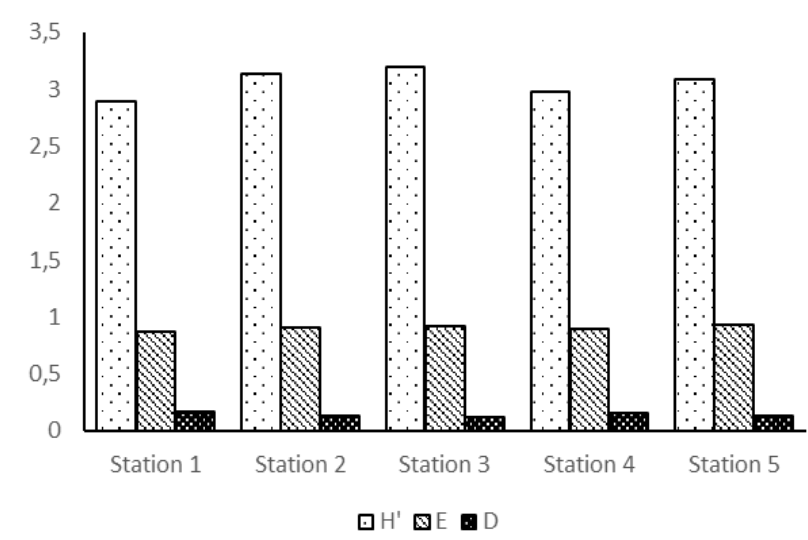

Figure 3. Results of the ecological index of gastropods community. H' (diversity index), E (evenness index), and C (dominance index)

Table 3. Mangrove density (ind/ha) in Ngurah Rai Forest Park, Bali, Indonesia

\begin{tabular}{lcccccc}
\hline \multicolumn{1}{c}{ Species } & \multicolumn{3}{c}{ Research location } & \multicolumn{2}{c}{ Total } \\
\cline { 2 - 6 } & S1 & S2 & S3 & S4 & S5 & 878 \\
Sonneratia alba & 733 & 611 & 89 & 833 & 3144 \\
Rhizophora apiculata & 544 & 122 & 311 & 211 & 322 & 1510 \\
Rhizophora mucronata & 0 & 400 & 878 & 0 & 0 & 1278 \\
Bruguiera gymnorrhiza & 211 & 0 & 67 & 0 & 44 & 322 \\
Avicennia marina & 0 & 0 & 67 & 0 & 78 & 145 \\
Xylocarpus granatum & 0 & 0 & 22 & 44 & 0 & 66 \\
Total & 1488 & 1133 & 1434 & 1088 & 1322 & 6465 \\
\hline
\end{tabular}

Note: S1: Mertasari Beach; S2: MIC Office; S3: Mati River; S4: Kedonganan Village; S5: Tanjung Benoa

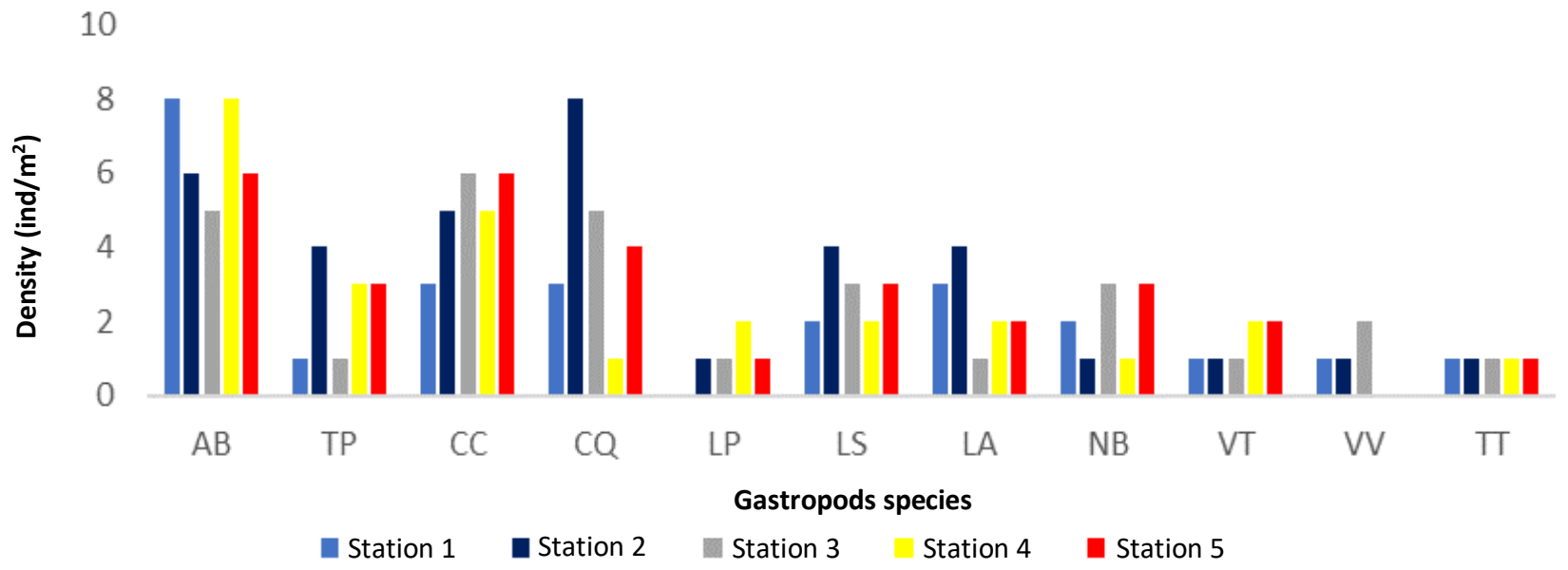

Figure 2. The density of gastropods species in Ngurah Rai Forest Park Bali, Indonesia. Note: AB: Assiminea brevicula; LA: Littoraria articulata; TP: Terebralia palustris; NB: Nerita balteata; CC: Cerithidea cingulata; VT: Vittoida turrita; CQ: Cerithidea quadrata; VV: Vittoida variegata; LP: Latirus polygonus; TT: Telescopium telescopium; LS: Littoraria scabra 


\section{Ecological index of gastropods community}

Ecological index values consist of diversity index ( $\left.\mathrm{H}^{\prime}\right)$, evenness index $(\mathrm{E})$, and dominance index $(\mathrm{C})$ can be used as a description of the gastropods community in Ngurah Rai Forest Park Bali. The results of the ecological index gastropods community can be seen in Figure 3.

Gastropods diversity was determined using the Shannon-Wiener diversity index. The diversity index value ranged between 2.89 to 3.2 indicating moderate to high diversity species richness (Figure 3) (Magurran 2004). According to $\mathrm{Gu}$ et al. (2016); Prasetya et al. (2017); Huang et al. (2020), diversity of gastropods can describe the stability of the ecosystems. The high diversity index value makes ecosystem existence said well, conversely, the low diversity index causes unbalanced gastropods habitat.

Evenness index values can indicate the presence or absence of dominance of species at research location (Ricotta et al. 2014; Kvalseth 2015). The results of the evenness index were in the range of 0.87 to 0.93 (Figure 3 ). The evenness index ranged from 0 to 1 . A site with a high evenness index indicates that no species dominate the site. Conversely, if a community has a low evenness index, the spread of the number of individuals within each species not the same and there is a tendency for one species to dominate (Shaheen et al. 2011; Zhang et al. 2012; Strong 2016). Based on the results of the research, the evenness index value was close to 1 so that the distribution of gastropods is good because the distribution of each individual is evenly distributed.

The results of the dominance value show the richness of species communities and the balance of a total of individuals of each species (Levin et al. 2015; Gilardoni et al. 2019). The results of the dominance index were in the range of $0.12-0.17$ (Figure 3). Dominance index value between $0<\mathrm{C}<0.5$ indicating no tendency of gastropods species dominate in study area. A low dominance index in the present study $(0.12-0.17)$ is in line with evenness index (0.87-0.93) recorded. The greater of evenness index value indicates the density of each species is relatively the same and there tends to be no domination by specific species. The absence of dominant species causes gastropod life not stressed. Therefore, it can be said that the gastropod habitat condition is stable because there are no species dominate the site.

\section{Association of gastropods and environmental characteristics}

Principal Component Analysis (PCA) results showed that gastropods spread to all research stations. Species $A$. brevicula scatters on the sand and silt substrates and adaptive to conditions of temperature, salinity, $\mathrm{pH}$, and dissolved oxygen. Meanwhile, A. brevicula has a negative correlation on clay substrate (Figure 4). This is supported by the various study by Liao et al. (2018) and Idrus et al. (2019). A. brevicula was widely distributed along the coast of China (Liao et al. 2018) and was also found adapted well on Rhizophora stylosa tress with characteristics of sand and mud substrates (Idrus et al. 2019). The wide distribution of A. brevicula indicates that these species very adaptive to the existing environmental conditions on the mangrove ecosystem. According to Premcharoen et al. (2016), the presence of $A$. brevicula can be used as an indicator of mangrove ecosystem health because of their tolerance to environmental variability.

Meanwhile, C. cingulata, C. quadrata, L. articulata, and $L$. scabra spread on clay substrate conditions with high C-organic content and had a negative relationship with sand substrate. According to several previous studies, $C$. cingulata, L. articulata, and L. scabra exist optimally on clay substrates Premcharoen et al. (2016); Wanthongchai and Pongruktham (2019). On the other hand, there was a negative relationship with the sand substrate because it had a rough size. The presence of a coarse substrate indicates that the substrate was deposited in an open area that is directly related to the high seas. The study site at station 1 and station 4 which were on the coastal area so that the influence of sea current can affect the substrate fraction composition. According to Eddy and Roman (2016); Gao et al. (2018); Soler et al. (2020), which the stronger current will be found coarse granules. Conversely, in waters with the weak current will be found smooth granules will be deposited. Smooth granules are closely related to the availability of C-organic content in the substrate. Generally, the higher smooth granules (clay), the higher Corganic content will be found in the mangroves area. This is consistent with study conducted by Serrano et al. (2016) and Chen et al. (2020) that clay has a good ability to storage $\mathrm{C}$-organic because it has dense pores while sand has large pores so that organic matter is easily carried by currents. The $\mathrm{C}$-organic content in the substrate is very important as a source of nutrients for gastropods in the mangrove ecosystems. However, if the C-organic content exceeds the threshold then it can be considered as a pollutant (Zhang et al. 2015; Laut et al. 2017; McAlister and Rott 2019).

\section{Association of gastropods and mangrove species}

Correspondence Analysis (CA) results show that gastropods species have different associations with mangrove species. Associations of gastropods and mangroves form two groups (Figure 5). The first group (purple circle) explained that the species $C$. cingulata, $T$. telescopium, $N$. balteata, $V$. turrita, $V$. variegata, $L$. polygonus, and L. scabra has a close relationship with $R$. apiculata and $R$. mucronata. Researchers in various studies have demonstrated a strong association of L. scabra (Littorinidae), N. balteata (Neritidae), C. cingulata and T. Telescopium (Potamididae) with clay substrate at middle zone towards intertidal areas (Haumahu and Uneputty 2018; Padovan et al. 2019; Laraswati et al. 2020). Clay substrate is suitable for the growth of $R$. apiculata and $R$. mucronata. According to several studies, $R$. mucronata was dominated in the research observation with a root system that can trap smooth granules to form a clay substrate (Setyawan and Ulummudin 2012; Robertson and Alongi 2016; Prabu and Gokul 2017). The roots system of $R$. apiculata and $R$. mucronata from branches and sticks to the soil which is commonly called the stilt roots. According to 
Strauch et al. (2012); Srikanth et al. (2015), stilt roots functions as a buffer for coastal ecosystems by trapping clay substrate and litter which will become food for gastropods.

Biplot (axes F1 and F2: $70.92 \%$ )

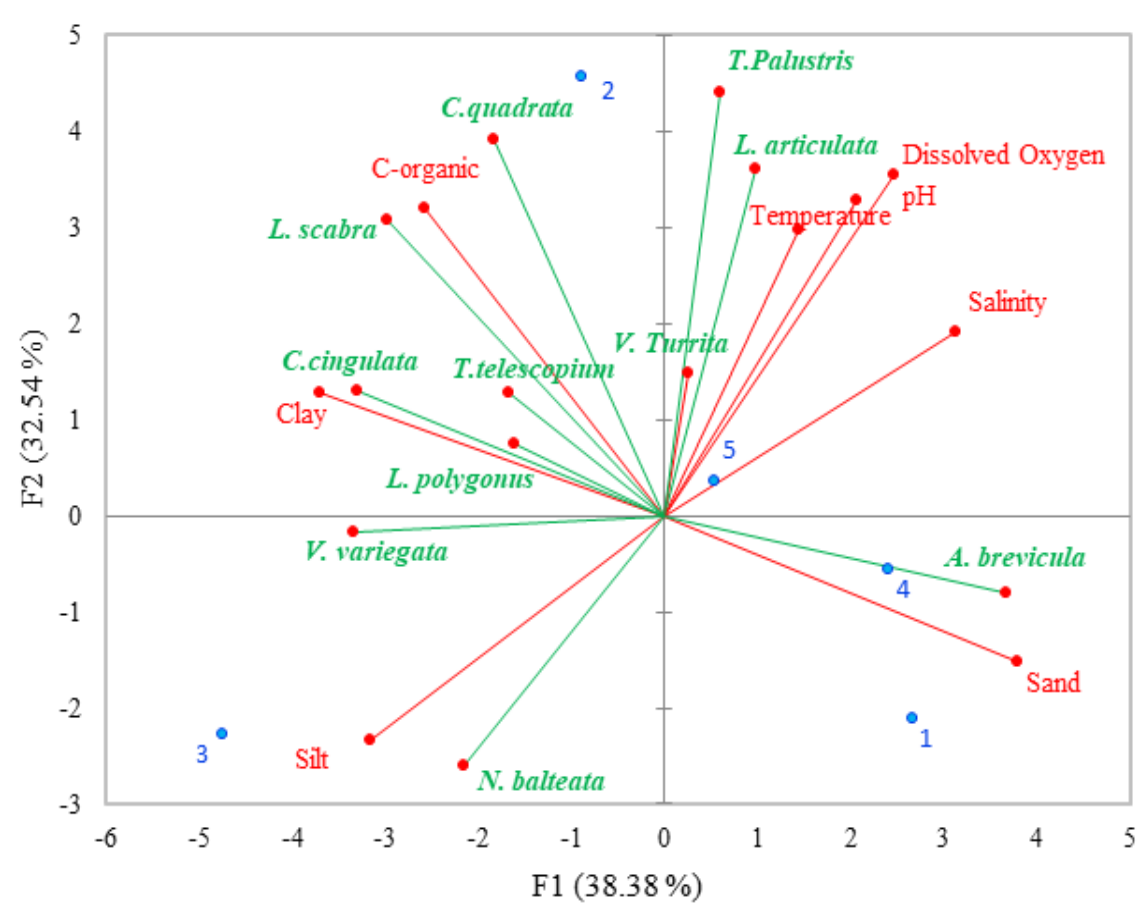

Figure 4. Principal component analysis gastropods distribution with environmental characteristics

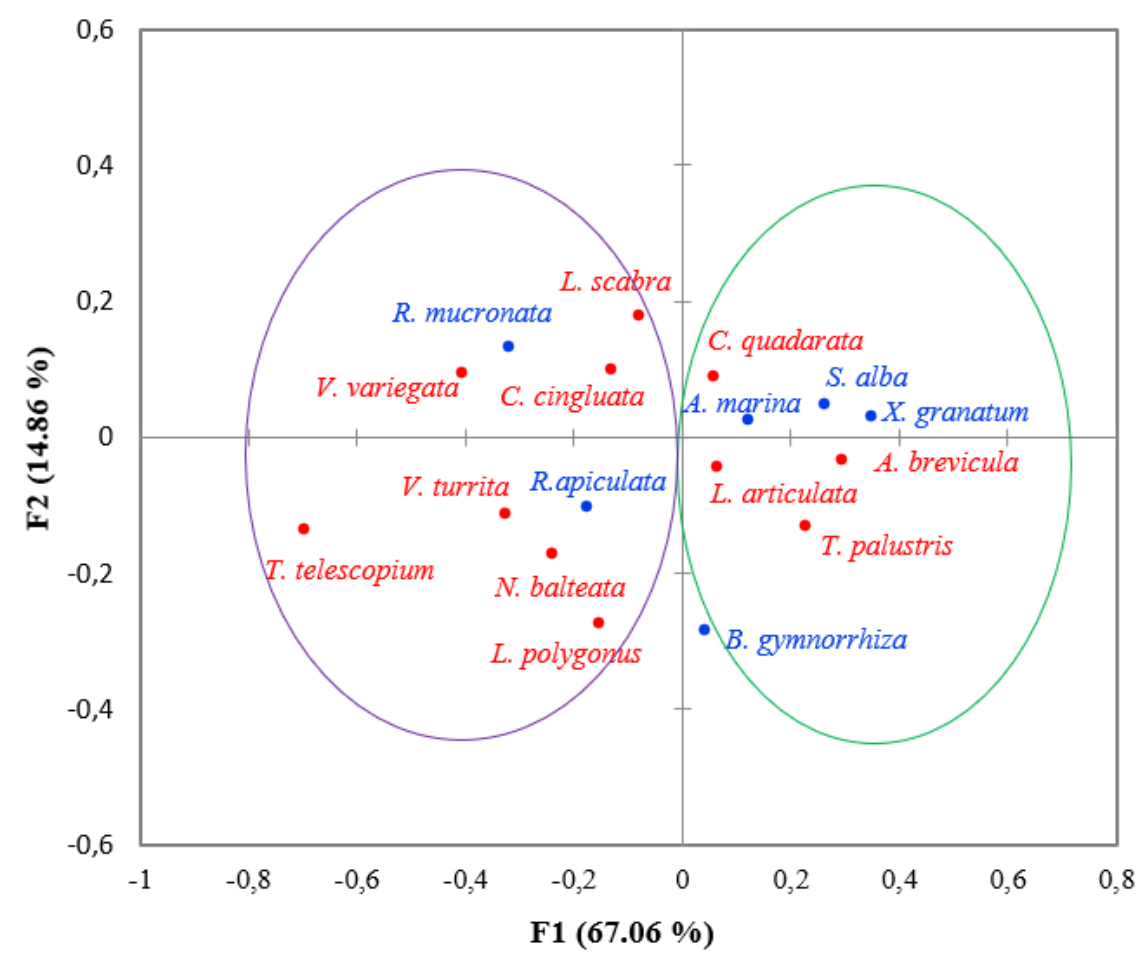

Figure 5. Correspondence analysis gastropods species with mangrove ecosystem 
The second group (green circle) shows the species of $A$. brevicula, C. quadrata, L. articulata, and T. palustris in close association with $S$. alba, A. marina, B. gymnorrhiza, and $X$. granatum. According to research conducted by Patria and Putri (2017) in Panjang Island Banten, T. palustris also was associated with $S$. alba mangroves that grow very well on sand and mud substrates. In addition, Idrus et al. (2019) also reported several gastropods species from Potamididae family $(C$. cingulata, C. quadrata, $T$. telescopium, and $T$. palustris) which assosiated with mangrove species of $S$. alba and A. marina in the southern coast of East Lombok. Meanwhile, Li et al. (2017) recorded distribution of $A$. brevicula in the intertidal zone along the Gulf of Xiamen, China. The intertidal zone is located on the coast which borders the terrestrial ecosystems (Nordlund et al. 2013; Wang et al. 2018). The intertidal zone is the narrowest because that zone is strongly influenced by tides. The existence of tides can cause water environmental parameters such as temperature, $\mathrm{pH}$, salinity, and dissolved oxygen to change at any time. Gastropods that live and can survive in the intertidal zone are commonly able to adapt to existing environmental conditions by moving to the terrestrial areas and immersing themselves in the sand or clay substrate to keep getting water supply. Roy and Nandi (2012); Namchote et al. (2015); Solanki et al. (2016); and Itsukushima et al. (2019) also reported distribution of $A$. brevicula species were able to live well in zone conditions that approached the coastline. This indicates that the species of A. brevicula in mangrove zonation near the sea which generally grows mangrove species of Avicennia sp. and Sonneratia sp.

Ecological index results of the gastropods community indicated that the gastropods are in good condition and evenly distributed with no species dominate the study area. Species of $A$. breviula were found on the sand substrate associated with S. alba, A. marina, B. gymnorrhiza, and X. granatum. Meanwhile, species of $C$. cingulata, $C$. quadarata, L. articulata, and L. scabra were found on clay substrate with high C-organic content and associated with $R$. apiculata and $R$. mucronata. As an outlook, the negative effect of the anthropogenic waste in these areas can disrupt the mangrove ecosystem. It would be interesting to investigate the influence of heavy metal content considering mangrove ecosystem has an important role in organisms.

\section{ACKNOWLEDGMENTS}

We extend our gratitude to all lecturers at the Environmental Sciences Study Program of Postgraduate Program at Udayana University for sharing, discussing, and expertise during my studies at the program. The authors also appreciate UPT Tahura Ngurah Rai Bali, Adi Wiryana, Eka Handrayana, and Agung Dharmayoga for all their help during fieldwork.

\section{REFERENCES}

Abdelhady AA, Abdelrahman E, Elewa AMT, Fan J, Zhang S, Xiao J. 2018. Phenotypic plasticity of the gastropod Melanoides tuberculata in the Nile Delta: A pollution-induced stabilizing selection. Mar Pollut Bull 133: 701-710.

Abdulkarim R, Akintoye AE, Oguwuike ID, Imhansoeleva TM, Philips IM, Ruth FB, Olubukola SO, Rasheed JO, Banji AO. 2011. Sedimentological variation in beach sediments of the barrier bar lagoon coastal system, South-Western Nigeria. Nat Sci 9 (9): 19-26.

Adeleke R, Nwangburuka C, Oboirien B. 2016. Origins, roles and fate of organic acids in soils: A review. S Afr J Bot 108: 393-406.

Ariyanto D. 2019. Food preference on Telescopium telescopium (Mollusca: Gastropoda) based on food sources in mangrove ecosystem. Plant Archives 19 (1): 913-916.

Asri FE, Zidane H, Maanan M, Tamsouri M, Errhif A. 2015. Taxonomic diversity and structure of the molluscan fauna in Oualidia Lagoon (Moroccan Atlantic Coast). Environ Monit Assess 187 (8): 545. DOI: 10.1007/s10661-015-4752-7.

Bachelet G, Montaudouin XD, Dauvin JC. 1996. The quantitative distribution of subtidal macrozoobenthic assemblages in Arcachon Bay in relation to environmental factors: A multivariate analysis. Estuar Coast Shelf Sci 42 (3): 371-391.

Barnard PL, Schoellhamer DH, Jaffe BE, McKee LJ. 2013. Sediment transport in the San Francisco Bay Coastal System: An overview. Mar Geol 345: 3-17.

Baroudi F, Alam JA, Fajloun Z, Millet. 2020. Snail as sentinel organism for monitoring the environmental pollution; a review. Ecol Ind 113: 106240. 10.1016/j.ecolind.2020.106240.

Barreto CR, Morissey EM, Wykoff DD, Chapman SK. 2018. Cooccurring mangrove and salt marshes differ in microbial community composition. Wetlands 38: 497-508.

Basyuni M, Ramayani, Hayullah A, Prayunita, Hamka M, Putri LA, Baba S. 2019. Growth of salt-secretor and non-salt secretor mangrove seedlings with varying salinity and their relations to habitat zonation. IOP Conf Ser Earth Environ Sci 236: 012050. DOI: 10.1088/17551315/236/1/012050.

Bengen DG. 2000. Sinopsis Teknik Pengambilan Contoh dan Analisis Data Biofisik Sumberdaya Pesisir. PKSPL-IPB, Bogor. [Indonesia].

Bengen DG. 2004. Pedoman Teknis Pengenalan dan Pengelolaan Ekosistem Mangrove. PKSPL-IPB, Bogor. [Indonesia]

Bloot SJ, Pye K. 2001. Gradistat: A grain size distribution and statistics package for the analysis of unconsolidated sediments. Earth Surf Proc Land 26: 1237-1248.

Boyd CE, Tucker CS, Viriyatum R. 2011. Interpretation of $\mathrm{pH}$, acidity, and alkalinity in aquaculture and fisheries. N Am J Aquacult 73 (4): 403-408.

Buncag MJJ, Esguerra WM, Linga AD. 2019. Community-based mangrove rehabilitation: The case of Calatagan Mangrove ParkMarine Protected Area, Batangas, Philippines. Int J Sci Mgmt Stud 2 (6): 95-102.

Chen Y, Ma D, Xia Y, Guo C, Yang F, Shao K. 2020. Characteristics of the mud shale reservoirs in coal-bearing strata and resource evaluation in the eastern margin of the Ordos Basin, China. Energ Explor Exploit 38 (2): 372-405.

Costa LD, Budiastuti MTHS, Sutrisno J, Sunarto. 2019. The diversity of plant species in a mangrove forest in the Coast of Metinaro, TimorLeste. IOP Conf Ser Earth Environ Sci 256: 1-12. DOI:10.1088/17551315/256/1/012026.

Das SK, Samantaray D, Sahoo SK, Pradhan SK, Samanta L, Thatoi H. 2019. Bioactivity-guided isolation of antidiabetic and antioxidant compounds from Xylocarpus granatum J. Koenig bark. 3 Biotech 9 (5):198. DOI: 10.1007/s13205-019-1711-y.

Dharma B. 2005. Recent \& Fossil Indonesian Shells. Conchbook, Germany.

Dimalen FK, Rojo MJA. 2018. Floral diversity of a mangrove forest in Cotabato City, Philippines. J Biol Environ Sci 13 (6): 117-123.

Dubuc A, Baker R, Marchand C, Waltham NJ, Sheaves M. 2019. Hypoxia in mangroves: Occurrence and impact on valuable tropical fish habitat. Biogeosci 16: 3959-3976.

Eddy EN, Roman CT. 2016. Relationship between epibenthic invertebrate species assemblages and environmental variables in Boston Harbor's intertidal habitat. Northeast Nat 23 (1): 45-66.

Efriyeldi E, Mulyadi A, Samiaji J. 2020. Condition of mangrove ecosystems in Sungai Apit Siak District based on standard damage 
criteria and quality indicators mangrove environment. IOP Conf Ser Earth Environ Sci 430: 012013. DOI: 10.1088/17551315/430/1/012013.

Farooq S, Siddiqui. 2020. Assessment of three mangrove forest systems for future management though benthic community structure receiving anthropogenic influences. Ocean Coast Manag 190: 105162. DOI: 10.1016/j.ocecoaman.2020.105162.

Gao GD, Wang XH, Song D, Bao X, Yin BS, Yang DZ, Ding Y, Li H, Hou F, Ren Z. 2018. Effects of wave-current interactions on suspended-sediment dynamics during strong wave events in Jiaozhou Bay, Qingdao, China. J Phys Oceanogr 48 (5): 1053-1078.

Gedan KR, Altieri AH, Feller I, Burrell R, Breitburg D. 2017. Community composition in mangrove ponds with pulsed hypoxic and acidified conditions. Ecosphere 8 (12): e02053. 10.1002/ecs2.2053

Geng X, Boufadel MC, Jackson NL. 2016. Evidence of salt accumulation in beach intertidal zone due to evaporation. Sci Rep 6: 31486. DOI $10.1038 /$ srep31486.

Gilardoni C, Giorgio GD, Bagnato E, Cremonte. 2019. Survey of trematodes in intertidal snails from Patagonia, Argentina: New larval forms and diversity assessment. J Helminthol 93: 342-351.

Gmach MR, Cherubin MR, Kaiser K, Ceri CEP. 2020. Processes that influence dissolved organic matter in the soil: A review. Sci Agric 77 (3): e20180164. DOI: 10.1590/1678-992X-2018-0164.

Gobler CJ, Baumann H. 2016. Hypoxia and acidification in ocean ecosystems: Coupled dynamics and effects on marine life. Biol Letters 12 (5): 20150976. DOI: 10.1098/rsbl.2015.0976.

Gu J, Zhou J, Wilson M, Jia K, Lv K, Xu Z. 2016. Species diversity and functional diversity of insects in Wuxijiang National Wetland Park, East China. Acta Ecol Sin 36: 386-391.

Haumahu S, Uneputty PA. 2018. Morphometric variation of ten species of Nerita (Molluscs: Gastropods) in rocky intertidal zone of Oma Village, Central Moluccas, Eastern Indonesia. Int J Fis Aquat Stu 6 (3): 276-280

Hilaluddin F, Yusoff FM, Natrah FMI, Lim PT. 2020. Disturbance of mangrove forest causes alterations in estuarine phytoplankton community structure in Malaysian Matang mangroves forest. Mar Environ Res 158: 104935. DOI: 10.1016/j.marenvres.2020.104935.

Huang H, Sun Y, Yu W, Ma Z, Tang K. 2020. Analysis of the characteristics of eco-exergy-based indices and diversity indices in the Zhoushan Archipelago, China. Environ Sci Pollut Res. DOI 10.1007/s11356-019-07544-2.

Idrus AA, Syukur A, Zulkifli L. 2019. The diversity of fauna in mangrove community: Success replanting of mangroves species in South Coastal East Lombok, Indonesia. J Phys Conf Ser 1402: 033042. DOI: $10.1088 / 1742-6596 / 1402 / 3 / 033042$

Itsukushima R, Yoshikawa H, Morita K. 2019. Relationship between physical environmental factors and presence of molluscan species in medium and small river estuaries. Estuar Coast Shelf Sci 218: 300309.

Jayachandran S, Chakraborty P, Ramteke D, Chennuri K, Chakraborty S. 2018. Effect of $\mathrm{pH}$ on transport and transformation of $\mathrm{Cu}$-sedimen complexes in mangrove systems. Mar Pollut Bull 133: 920-929.

Kawaida S, Nanjo K, Kanai T, Kohno H, Sano M. 2017. Microhabitat differences in crab assemblage structures in a subtropical mangrove estuary on Iriomote Island, southern Japan. Fish Sci 83: 1007-1017.

Kherif F, Latypova A. 2020. Principal component analysis. Machine Learn. DOI:10.1016/B978-0-12-815739-8.00012-2

Kitamura S, Anwar C, Chaniago A, Baba S. 1997. Handbook of Mangrove in Indonesia: Bali and Lombok. JICA and ISME, Japan.

Koch EW, Barbier EB, Silliman BR, Reed DJ, Perillo GME, Hacker SD, Wolanki E. 2009. Non-linearity in ecosystem services: Temporal and spatial variability in coastal protection. Front Ecol Environ 7 (1): 29 37.

Koch EW. 2001. Beyond light: Physical, geological, and geochemical parameters as possible submersed aquatic vegetation habita requirements. Estuaries 24 (1): 1-17.

Krebs CJ. 1989. Ecological Methodology. Harper and Row Publishers Inc, New York.

Kvalseth TO. 2015. Evenness indices once again: critical analysis of properties. SpringerPlus 4, 232. DOI: 10.1186/s40064-015-0944-4.

Laraswati Y, Soenardjo N, Setyati WA. 2020. Komposisi dan kelimpahan gastropoda pada ekosistem mangrove di Desa Tireman, Kabupaten Rembang, Jawa Tengah. J Mar Res 9 (1): 41-48. [Indonesia]

Latupeirissa LN, Leiwakabessy F, Rumahlatu D. 2020. Species density and shell morphology of gold ring cowry (Monetaria annulus,
Linnaeus, 1758) (Mollusca: Gastropoda: Cypraeidae) in the coastal waters of Ambon Island, Indonesia. Biodiversitas 21 (4): 1391-1400.

Laut L, Martins MVA, Frontalini F, Ballalai JM, Belart P, Habib R, et al. 2017. Assessment of the trophic state of a hypersaline-carbonatic environment: Vermelha Lagoon (Brazil). PLoS ONE 12(9): e0184819. DOI: 10.1371/journal.pone.0184819.

Levin LA, Mendoza GF, Grupe BM, Gonzalez JP, Jellison B, Rouse G, Thurber AR, Waren A. 2015. Biodiversity on the rocks: macrofauna inhabiting authigenic carbonate at Costa Rica Methane Seeps. PLoS One 10 (7): e0131080. DOI: 10.1371/journal.pone.0131080.

Li Y, Liu M, Jin L, Liu D. 2017. Variation characteristics of macrobenthic communities in the intertidal zone of Dajing, Southern Xiamen Bay. Adv Mar Sci 4 (3): 102-110.

Liao Y, Shou L, Tang Y, Gao A, Chen Q, Yan X, Chen J. 2018. Influence of two non-indigenous plants on intertidal macrobenthic communities in Ximen Island Special Marine Protected Area, China. Ecol Eng 112: 96-104

Lin CW, Kao YC, Chou MC, Wu HH, Ho CW, Lin HJ. 2020. Methane emissions from subtropical and tropical mangrove ecosystems in Taiwan. Forest 11(4): 470. DOI: 10.3390/f11040470.

Litaay M, Deviana M, Priosambodo. 2017. Biodiversity and distribution of gastropods at seagrass meadow of Balangdatu Waters Tanakeke Island South Sulawesi Indonesia. Int Appl Bio 1 (2): 67-75.

Lo M, Narulita S, Ickowitz A. 2019. The relationship between forests and freshwater fish consumption in rural Nigeria. PLoS One 14(6): e0218038. DOI: 10.1371/journal.pone.0218038.

Lugina M, Alviya I, Indartik, Pribadi MA. 2017. Strategi keberlanjutan pengelolaan hutan mangrove di Tahura Ngurah Rai Bali. Jurnal Analisis Kebijakan Kehutanan 14 (1): 61-77. [Indonesia]

Magurran AE. 2004. Measuring Biological Diversity. Blackwell Publishing, Oxford, England.

Marley GSA, Deacon AE, Phillip DAT, Lawrence AJ. 2020. Mangrove on mudflat: Prioritising fish habitat for conservation in a turbid tropical estuary. Estuar Coast Shelf Sci 240: 1-8.

McAlister R, Rott AS. 2019. Up on the roof and down in the dirt: Differences in substrate properties (SOM, potassium, phosphorus and $\mathrm{pH})$ and their relationships to each other between sedum and wildflower green roofs. PLoS ONE 14 (12): e0225652. DOI: 10.1371/journal.pone.0225652.

Ministry of Environment. 2004. Decree of the Minister of Environment. No.51 of 2004 about sea water quality standards, Jakarta. [Indonesia]

Ministry of Environment. 2004. Decree of the Minister of Environment No.201 of 2004 about guidelines determination of mangroves damage, Jakarta. [Indonesian]

Mitra A. 2018. Salinity: A primary growth driver of mangrove forest. Sustain For 1: 1-9. DOI: 10.24294/sf.v1i2.191

Mitra A. 2019. Mangrove: A nutrient retention box. In: Mitra A (eds). Mangrove Forest in India. Springer, Switzerland.

Muhammad-Nor SM, Huxham M, Salmon Y, Duddy SJ, Mazars-Simon A, Mencuccini M, Meira P, Jackson G. 2019. Exceptionally high mangrove root production rates in the Kelantan Delta, Malaysia; An experimental and comparative study. For Ecol Manag 444: 214-224.

Mulla TM, Chavan NS. 2017. Mangrove diversity along the coast of Ratnagiri, Maharashtra. Curr Biol 8: 123-126.

Namchote S, Sritongtae S, Butnin S, Wongwain P, Krailas D. 2015. Larval stage of trematodes obtained from brackish water snails in the central and east coast of the Gulf of Thailand. Sci Res Essays 10 (11): 386-401.

Nordlund LM, Torre-Castro M, Erlandsson J, Conand C, Muthiga N, Jiddawi N, Gullstrom M. 2013. Intertidal zone management in the Western Indian Ocean: Assessing current status and future possibilities using expert opinions. Ambio 43 (3): 1006-1019.

Norris BK, Mullarney JC, Bryan KR, Henderson SM. 2019. Turbulence within natural mangrove pneumatophore canopies. J Geophys Res 124 (4): 2263-2288.

Nurprasaja GP. 2018. Community structure of Gastropoda and relation to mangrove ecosystem at Ngurah Rai Forest Park Bali. [Thesis]. Bogor Agricultural University, Bogor. [Indonesia]

Padovan A, Kennedy K, Rose D, Gibba K. 2019. Microbial quality of wild selfish in a tropical estuary subject to treated effluent discharge. Environ Res 181: 1-10.

Patria MP, Putri SA. 2017. The role of Terebralia (Gastropoda: Potamididae) in carbon deposits at mangrove forest Pulau Panjang, Serang-Banten. AIP Conference Proceedings 1844. DOI: 10.1063/1.4983438. 
Pazira AR, Salehi H, Obeidi R. 2019. Identification and investigation of species diversity and richness of the Gastropoda in intertidal zone of Bushehr Port coastal area (the Persian Gulf waters). Iran J Fish Sci 18 (2): $355-370$

Peng Y, Diao J, Zheng M, Guan D, Zhuang R, Chen G, Lee SY. 2016 Early growth adaptability of four mangrove species under the canopy of an introduced mangrove plantation: Implications for restoration. Forest Ecol Manag 373: 179-188.

Peng Y, Zhang M, Lee SY. 2017. Food availability and predation risk drive the distributional patterns of two pulmonate gastropods in a mangrove-saltmarsh transitional habitat. Mar Environ Res. DOI: 10.1016/j.marenvres.2017.07.005.

Polidoro BA, Carpenter KE, Collins L, Duke NC, Ellison AM, Ellison JC, Farnsworth EJ, Fernando ES, Kathiresan K, Koedam NE. 2010. The loss of species: Mangrove extinction risk and geographic areas of global concern. PLoS One 5 (4): e10095. DOI: 10.1371/journal.pone.0010095.

Prabu E, Gokul S. 2017. Mangrove: An incredible ecosystem for sustainable fisheries. J Aquacult Trop 32 (3): 397-411.

Prarikeslan W. 2016. Oseanografi. Penerbit Kencana, Jakarta. [Indonesia]

Prasetya JD, Ambariyanto, Supriharyono, Purwanti F. 2017. Mangrove health index as part of sustainable management in mangrove ecosystem at Karimunjawa National Marine Park Indonesia. Adv Sci Lett 23 (4): 3277-3282.

Premcharoen S, Witirawat S, Tharapoom P. 2016. Molluscan fauna in Bang Taboon Mangrove Estuary, Inner Gulf of Thailand: Implications for conservation and sustainable use of coastal resources. MATEC Web of Conf 60: 1-5.

Priosambodo D, Juhriah, Alam M, Al-Anshari M, Putra AW. 2019 Species composition and structure of mangrove in Tamo Rocky Cliff Beach Majene (West Sulawesi, Indonesia). J Phys Conf Ser 1341: 022021. DOI: 10.1088/1742-6596/1341/2/022021.

Rajwa-Kuligiewicz A, Bialik RJ, Rowinski PM. 2015. Dissolved oxygen and water temperature dynamics in lowland rivers over various timescales. J Hydrol Hydromech 63: 353-363.

Reguera P, Couceiro L, Fernandez N. 2018. A review of the empirical literature on the use of limpets Patella spp. (Mollusca: Gastropoda) as bioindicators of environmental quality. Ecotox Environ Safe 148: 593-600

Reyes TG, Crisosto JM. 2016. Characterization of dissolved organic matter in river water by conventional methods and direct sample analysis-time of flight mass spectrometry. J Chem. DOI: $10.1155 / 2016 / 1537370$.

Ricotta C, Bacaro G, Moretti M. 2014. A new measure of functional evenness and some of its properties. PLoS One 9 (8): e104060. DOI 10.1371/journal.pone.0104060.

Robertson AI, Alongi DM. 2016. Massive turnover rates of fine root detrital carbon in tropical Australian mangroves. Oecologia 180: 841 851

Roy M, Nandi NC. 2012. Distribution pattern of macrozoobenthos in relation to salinity of Hugli-Matla Estuaries in India. Wetlands 32: 1001-1009.

Sane E, Fatela F, Cabral MC, Brotas V, Drago T, Oliveira A. 2020 Assessment of organic matter preservation and coastal constraints (SE Algarve, Portugal). Reg Stud Mar Sci 34: 1-13

Savic A, Randelovic V, Dordevic M, Pesic V. 2016. Assemblages of freshwater snails (Mollusca: Gastropoda) from the Nisava River, Serbia: Ecological factors defining their structure and spatial distribution. Acta Zool Bulg 68 (2): 235-242.

Serrano O, Lavery PS, Duarte CM, Kendrick GA, Calafato A, York PH, Steven A, Macreadie PI. 2016. Can mud (silt and clay) concentration be used to predict soil organic carbon content within seagrass ecosystems?. Biogeosci 13: 4915-4926.

Setyawan AD, Ulumuddin YI. 2012. Species diversity of Rhizophora in Tambelan Island, Natuna Sea, Indonesia. Biodiversitas 13 (4): 172-177.

Shah K, Kamal AHN, Rosli Z, Hakeem KR, Hoque MM. 2016. Composition and diversity of plants in Sibuti mangrove forest, Sarawak, Malaysia. Forest Sci Technol 12 (2): 70-76.

Shaheen H, Khan SM, Harper DM, Ullah Z, Qureshi RA. 2011. Species diversity, community structure, and distribution patterns in Western Himalayan Alpine Pastures of Kashmir, Pakistan. Mt Res Dev 31 (2): 153-159.

Shantelle F, Christian D, Christoper F. 2018. Decomposition as a regulator of carbon accretion in mangroves: A review. Ecol Eng 114: 173-178
Sheaves M, Dingle L, Mattone C. 2016. Biotic hotspots in mangrovedominated estuaries: Macro-invertebrate aggregation in unvegetated lower intertidal flats. Mar Ecol Prog Ser 556: 31-43.

Solanki D, Kanejiya J, Beleem I, Gohil B. 2016. Checklist of intertidal marine fauna in mangrove ecosystem, Ghogha Coast, Gulf of Khambhat, India. J Entomol Zool Stud 4 (4): 1281-1284

Soler M, Colomer J, Folkard A, Serra T. 2020. Particle size segregation of turbidity current deposits in vegetated canopies. Sci Total Environ 703: 134784. DOI: 10.1016/j.scitotenv.2019.134784

Sreelekshmi S, Nandan SB, Kaimal SV, Radhakrishnan CK, Suresh VR. 2020. Mangrove species diversity, stand structure, and zonation pattern in relation to environmental factors-a case study at Sundarban Delta, East Coast of India. Reg Stud Mar Sci 35: 1-31.

Sreelekshmi S, Preethy CM, Varghese R, Joseph P, Asha CV, Nandan SB, Radhakrishnan CK. 2018. Diversity, stand structure, and zonation pattern of mangroves in Southwest Coast of India. J Asia Pac Biodivers 11 (4): 573-582.

Srikanth S, Lum SKY, Chen Z. 2015. Mangrove root: Adaptations and ecological importance. Trees 30 (2): 451-465.

Strauch AM, Cohen S, Ellmore GS. 2012. Environmental influences on the distribution of mangroves on Bahamas Island. J Wet Eco 6: 16-24.

Strong WL. 2016. Biased richness and evenness relationships within Shannon-Wiener index values. Ecol Ind 67: 703-713.

Strosser E. 2010. Methods for determination of labile soil organic matter: An overview. J Agrobiol 27 (2): 49-60.

Suartini NM, Sudaryanto, Sudatri NW. 2013. Inventarisasi jenis molusca di Mangrove Information Center Taman Hutan Raya Ngurah Rai Bali. Jurnal Penelitian 17 (1): 1-9. [Indonesia]

Uncles RJ, Stephens. 2011. The effect of wind, runoff and tides on salinity in a strongly tidal sub-estuary. Estuar Coast Shelf Sci 34: 758-774.

Villate F, Iriarte A, Uriarte I, Sanchez I. 2017. Seasonal and interannual variability of mesozooplankton in two contrasting estuaries of the Bay of Biscay: Relationship to environmental factors. J Sea Res 130: 189203.

Virgulino-Junior PCC, Gardunho DCL, Silva DNC, Fernandes MEB. 2019. Wood density in mangrove forests on the Brazilian Amazon coast. Trees 34: 51-60.

Wang J, Cai C, Li Y, Hua M, Wang J, Yang H, Zheng P, Hu B. 2018. Denitrifying anaerobic methane oxidation: a previously overlooked methane sink in intertidal zone. Environ Sci Technol 53 (1): 203-212.

Wang XY, Xie WM, Zhang D, He Q. 2016. Wave and vegetation effects on flow and suspended sediment characteristics: A flume study. Estuar Coast Shelf Sci 182: 1-11.

Wanthongchai P, Pongruktham O. 2019. Mangrove Cover, Biodiversity, and Carbon Storage of Mangrove Forests in Thailand. Springer, Switzerland.

Widyastuti A, Yani E, Nasution EK, Rochmantino. 2018. Diversity of mangrove vegetation and carbon sink estimation of Segara Anakan Mangrove Forest, Cilacap, Central Java, Indonesia. Biodiversitas 19 (1): 246-252.

Wijayasinghe MM, Jayasuriya KMGG, Gunatilleke CVS, Gunatilleke IAUN, Walck JL. 2018. Effect of salinity on seed germination of five mangroves from Sri Langka: Use of hydro time modeling for mangrove germination. Seed Sci Res 29 (1): 1-9. DOI: 10.1017/S0960258518000405

Xu L, Wang M, Xin C, Liu C, Wang W. 2019. Mangrove distribution in relation to seasonal water salinity and ion compartmentation: A field study along freshwater-dominated river. Hydrobiol 847: 549-561.

Zamani NP, Gazali M, Batubara I. 2015. The study of tyrosinase and antioxidant activity of Xylocarpus granatum Koenig seed kernel extract toward evidence based indigenous knowledge from Togean Archipelago, Indonesia. J Marine Sci Res Dev 5: 168. DOI: 10.4172/2155-9910.1000168

Zhang H, John R, Peng Z, Yuan J, Chu C, Du G, Zhou S. 2012. The relationship between species richness and evenness in plant communities along a successional gradient: a study from sub-alpine meadow of the Eastern Qinghau-Tibetan Plateau, China. PLoS One 7 (11): e49024. DOI: 10.1371/journal.pone.0049024.

Zhang Y, Wang L, Hu Y, Xi X, Tang Y, Chen J, Fu X, Sun Y. 2015. Water organic pollution and eutrophication influence soil microbial processes, increasing soil respiration of estuarine wetlands: Site study in Jiuduansha Wetland. PLoS One 10 (5): e0126951. DOI: 10.1371/journal.pone.0126951. 